\title{
Some Notes on the Regeneration of Coral Reef Ecosystems
}

\section{Yuri Ya. Latypov}

A.V. Zhirmunsky Institute of Marine Biology, National Scientific Center of Marine Biology FEB RAS, Vladivostok, Russia

Email: yuri.latypov@mail.ru

How to cite this paper: Latypov, Y.Ya. (2016) Some Notes on the Regeneration of Coral Reef Ecosystems. Open Access Library Journal, 3: e3133. http://dx.doi.org/10.4236/oalib.1103133

Received: October 12, 2016

Accepted: November 1, 2016

Published: November 4, 2016

Copyright $\odot 2016$ by author and Open Access Library Inc.

This work is licensed under the Creative Commons Attribution International License (CC BY 4.0).

http://creativecommons.org/licenses/by/4.0/

\begin{abstract}
The current research is on fossil and recent coral reef ecosystem by traced processes of recovery after damage of different species. Examples of regeneration of artificially planted fragments of various species of scleractinian and reconstruction of part of the ecosystem of the reef are presented. Particular attention is drawn to the possibility of regeneration after typhoons and anthropogenic impacts.
\end{abstract}

\section{Subject Areas}

Ecosystem Science, Marine Biology

\section{Keywords}

Reef, Ecosystem, Fossil, Recent

\section{Introduction}

Technological progress leads to the fact that humanity completely melts all great power over nature. But so far, unfortunately, due to the use of this power, people strike out more often without anticipating outcomes and make such use unfit by increasing amounts of natural resources. According to the Global Coral Reef Monitoring Network (GCRMN), 20\% of all coral reefs have been destroyed by human activities. The main causes of coral reef devastation are general global problems: climate warming and increasing acidity of oceanic waters through carbon dioxide emissions to the atmosphere, increased eutrophication and sedimentation of coastal waters, which cut fish stocks, and the barbaric attitude of the residents of coastal areas towards sea inhabitants.

Only permanently damaging anything, we are after a while, when it is already hopelessly late, we recall and begin to appreciate the lost. Convinced of the urgent need to restore the once destroyed parts of the biosphere, we must, of course, take vigorous ac- 
tion. This requires proper measures, based on scientific advice. First, you need to find out how we have considered and planned for the restoration (or reconstruction) of ecosystem to be adapted to the regenerative processes, which is usually able to withstand destruction and is acquired in the course of organic evolution [1].

\section{Materials and Methods}

In 2005 and 2013, during expeditions on the R/V Akademic Oparin, the species composition and distribution of scleractinian, common species of macrobenthos and community structure in each of the reef zones near coastal reefs of Vietnamese were studied using SCUBA. The work was carried out via standard hydrobiological technique using counting frames and transects [2]. Using frames that were divided into 100 squares of $10 \mathrm{~cm}^{2}$ along a 100 - 200 meter transect, we assessed the number of common species of molluscs and echinoderms, as well as that of branchy, massive, encrusting, and foliase colonies of scleractinian and the degree of their substrate coverage. The index of species diversity was determined by the formula: $H=-\sum[(n i / N)(\ln n i / N)]$, where $H$ is the Shannon index; $n i$ is the number of individuals that belong to the $I$ species; and $N$ is the total number of individuals. For photographic treatment of the community composition and species diversity of scleractinian, more than 2500 photos of the general appearance of reef communities and underwater landscapes that were shot with Olympus and Lumix digital cameras were used.

\section{Result and Discussion}

\subsection{General Provisions}

Reef ecosystem formed about 400 million years ago [3] [4] [5]. A characteristic feature is its confinement to the tropical and subtropical regions, the upper part of the euphotic zone, and the near-surface zone of the sea with a most wave activity. All modern coral reefs are located in areas with high tectonic activity of the Earth's crust. The fossil coral buildings we often find among vivo buried not redeposit, but overturned and broken off massive branching colonies, both covered with the same rainfall.

The most common part of the fossil and modern reef systems and their universal part at all times was the organogenic detritus material. This shows a natural continuous process of the wave of destruction, which is developing the reef ecosystem. To make sure the sustainable existence of the reef should be as adapted to recover rapidly destroyed by its abiotic and biotic parts. In this regard, the reef can be recognized by the system extremely resistant to mechanical stress. This is evidenced by observations of different years on the restoration of both individual colonies and entire coral ecosystems exposed to catastrophic hurricanes (Funafuti Atoll, 1972, [6] tsunami (the reefs of Viti-Levu, 1961), and even the atomic bomb (Bikini Atoll, 1946), and recent typhoons in the Atlantic and Indo-Pacific [7] [8] [9] [10] [11]. Table 1 shows which part of the reef subjected to maximum destruction under the action of damaging factors.

Ancient and modern corals are able to repair damaged parts of the body and even 
Table 1. Effects of various influence factors on the reef.

\begin{tabular}{cc}
\hline Influence factor & Facieses reef zone \\
\hline Storm & Reef flat, the upper part of the battres \\
Tsunami & The same \\
Catastrophic outflow & Reef flat \\
Downpour & Reef flat \\
Assault predators & All reef zone except reef flat \\
Pollution & The entire reef \\
Atomic explosion & The upper part of the reef \\
\hline
\end{tabular}

walling foreign small and medium-sized objects that prevent the normal animal life. The phenomenon of regeneration is well developed in many invertebrates, including coelenterates. It is known from the fossil and modern corals [12] [13] [14]. Any strong changes in the growth of colonies are not observed. First the wreckage tightened coenosarcs then cenenchyme and finally fully covered corallites, packing and arrangement of which is similar to that of intact branches growing colonies (Figure 1). As revealed in experiments on Y. Loya Stylopora pistilata [15] and Yu. Latypov 14 species [1] [16], in the first two months of the regeneration of damaged and transplanted corals were growing twice as fast as the control. It was also shown that especially damaged colonies restored the original appearance, and significant differences between the rate of growth of damaged and control colonies were detected [1] [17].

\subsection{Fossil Reefs}

The Ordovician and Silurian seas of Siberia, the North-East Russia, Podolia, were distributed to many coral stromatopora construction [18]. The base of one such bioherm folded elliptic colonies stromatoporas height up to $21 \mathrm{~cm}$ in diameter and $40 \mathrm{~cm}$. Repeating the top form of colonies on them rose ribbon-like cortical stromatoporas, and they settled domed colonies of coral Mesosolenia festiva (Figure 2). Four successive generations of crustose stromatopora, grew on each other and separated clear boundaries. The thickness of the colonies was $1.5-2 \mathrm{~cm}$, length-20 $-50 \mathrm{~cm}$. On the top layer, these stromatoporas in the lifetime position are filled with coral colony $M$. festiva. Its upper surface is partly covered by detritus limestone, the other part was overgrown crust ate stromatoporas. It is clearly seen as an almost back filled colony stromatoporas beginning to regenerate, but the sediment supply rate increased by destroying the colony. As a rule, after experiencing a serious breach in the ancient reef communities first and most invasive forms were quickly regenerated stromatoporas, sometimes solitary corals.

\subsection{Situation on Recent Reefs}

On modern reefs a different picture of destruction and regeneration. In October 1961 Hurricane Katie, the last of the reefs British Honduras, destroyed almost all living corals in the more than 100-mile zone. On the outer slope of the reef have disappeared all living corals in the central band of the hurricane. Survivors of the storm remains of corals were only in the zone of moderate damage to 60 miles from the center line of the 


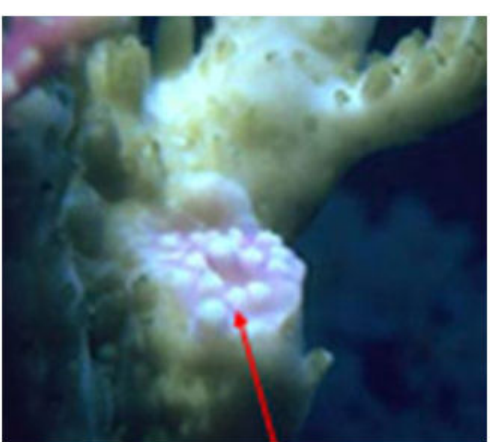

(a)

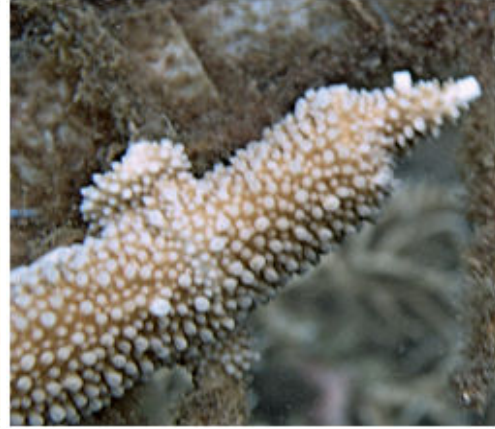

(b)

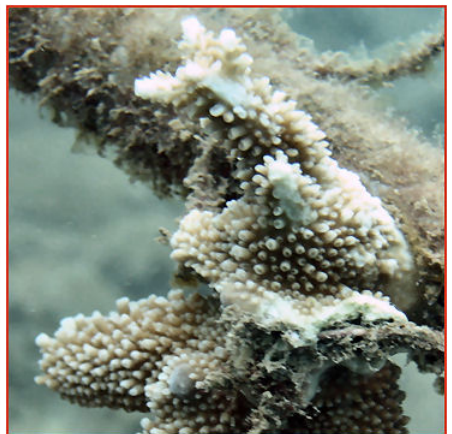

(c)

Figure 1. Regeneration of coral damage: (a) coenosarcs delay and restore corallites, (b) restoration branch of the colony, (c) immurement foreign object and shape recovery colony.

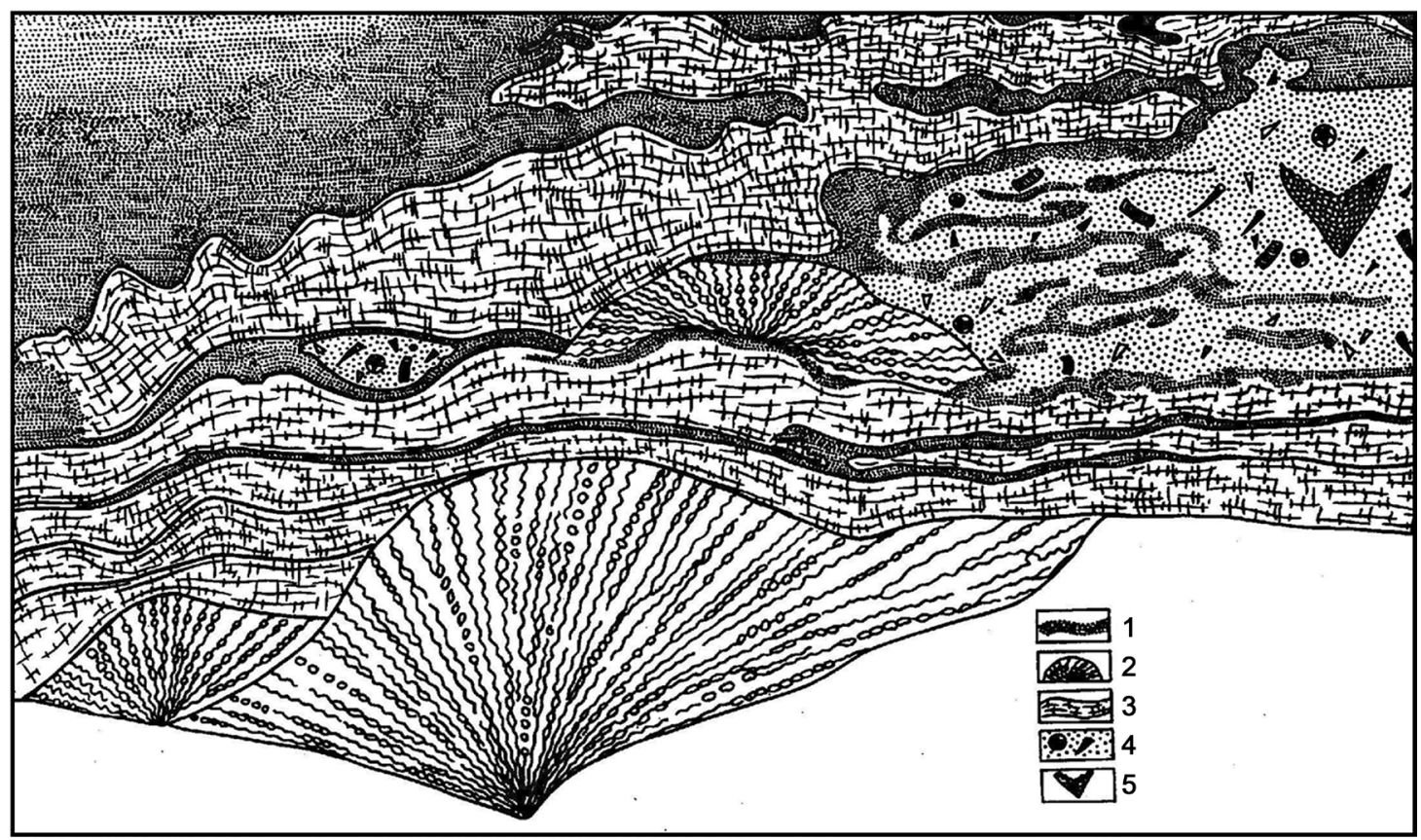

Figure 2. Fossil reef. 1-limescale, 2-colony tabulates, 3-stromatoporas, 4-detritus, 5-cystiphor rugosa.

hurricane. In 1965, the reef was examined and photographed from the air in the space of 55 miles [19]. As far as could be seen in the depth of the vertical reef, it was free of coral, probably due to the occurrence of underwater ravines. Numerous spots with dense thickets live Acropora were found away from the main area of destruction. D. Stoddart singled out the following areas of destruction and regeneration.

1) Strip the complete destruction of living coral and the lack of regeneration, extending less than 15 miles to the north and 12 miles south of the center of the storm line.

2) Keep the front line of the reef, but with dead corals is still regenerating, extends from 12 to 20 miles to the south of the central line of the hurricane.

3) More or less untouched reef edge with areas of surviving corals migrating to rich coral thickets at a distance of 25 miles to the south of the storm line.

4) Destruction or lowest quickly recovering at a distance of more than 25 miles from 
the track of the storm.

In the previous recovery of the reef after the devastating hurricane in 1931 it took 10 to 20 years [20]. Stoddart [19] suggested that this time will take at least 20 - 25 years. Under the influence of various factors on the reef, it usually remains a significant weight and length of the undisturbed ecological communities, serving as a source of genetic material for recovery.

When the storm (hurricane) and similar to them by the action of the devastation produced by the tsunami, and even nuclear explosions, the most important factor is the current mechanical shock waves breaking corals, calcareous algae, and mixing the substrate in the wreckage. Turbulent flows of water and suspended in it a grain of sand cut soft living body from the wreckage, but there are always lots of colonies containing live polyps or polyps group capable of rapid regeneration. All free abrade the substrate surface in a very short period covered by the film crimson calcareous algae, for 1 - 2 years occupying all available space. Only broken off and settled in the hollows, branched colonies regenerated, forming a basis for reviving the ecosystem (Figure 3). First Settlers regenerating and emerging ecosystems are the most eurybiontic, so-called opportunistic form: Pocillopora damicomis, Acropora formosa, A. hyacinthus, A. squamosa et al [1] [16] [21] [22] [23]. In the ancient (Paleozoic) settlements active growth of coral ecosystems, as a rule, begins with buildings chain Cateniporidae either phaceloid Siringoporidae [23].

The normal course of environmental succession on the atoll of Funafuti after exposure to Baby Hurricane in 1972 traced by us in the south-eastern tip of the island Fatato. After 1.5 years after the hurricane all the underwater reef platform is entirely covered with crimson calcareous algae. Only at the edges of the rare half-meter grooves growing small colonies Pocillopora, Millepora, Acropora, reaches a height of $3-8 \mathrm{~cm}$. Algal cover is dotted with traces of teeth of sea urchins and fish [23]. With the defeat of the reef during low tide disaster, especially if it is accompanied by heavy rains, there is a mass suffocation animals caught in the zone of the damaging factors. Regeneration occurs at the expense of reserves from the deeper parts of the reef. Observations on the regeneration of coral reefs and the population of man-made structures in the Gulf of

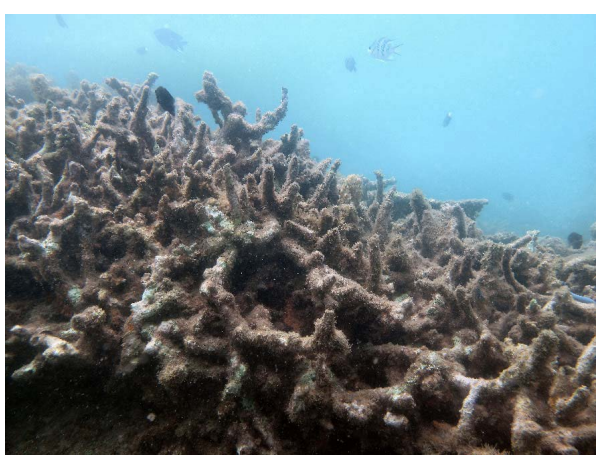

(a)

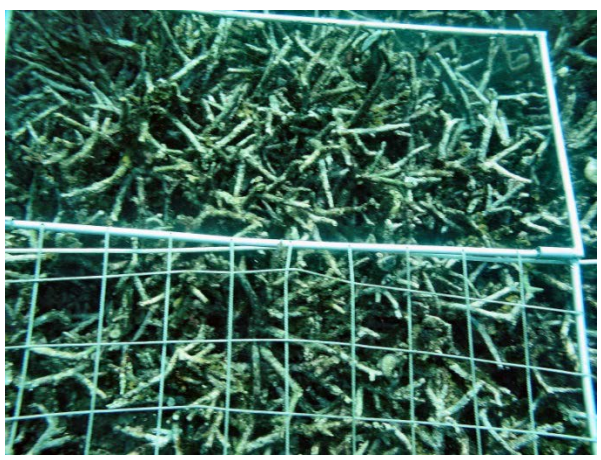

(b)

Figure 3. Physical destruction and covering Acropora mono-colony with sediments: (a) Ku Lao Cham, (b) Tcho Chu Islands. 
Eilat (Aqaba) Red Sea [24] showed the same direction of these processes. Particularly emphasize the role of sea urchins-scraper limiting the spread of calcareous algae and find the outcome of the competition for the habitat between algae and corals [25]. On the reefs of the Red Sea coast of Sudan established a relationship between the density of settlements sea urchins Echinometra matkaei, Heterocentrotus mammillatus and Diadema setosum, the proliferation of algae and the rate of re-colonization of corals [26].

\subsection{Changes and Restoration of Reef Community after Typhoon}

In October of 2006, 10 provinces of Central Vietnam went through a powerful Sangshen typhoon. According to data provided by the meteorological center wind spid exceeded $133 \mathrm{~km} / \mathrm{h}$ and sometimes reached $160 \mathrm{~km} / \mathrm{h}$. Heavy pouring rains, caused by the natural disaster, resulted in a fast rise of water level in local rivers. In many areas' precipitation level reached $200-230 \mathrm{~mm}$. Erosion of rice fields, coastal and beach areas caused the loss of $80 \%$ of mangrove bushes and $95 \%$ of coral reefs (based on an unpublished UNU-IAS Seminar Report). As is known, torrents of storm sewage are characterized by great desalination and turbidity due suspended matter, which is harmful for coral communities and results in their partial or at times complete mortality (Table 2).

In 1987 the species composition on various reefs ranged from 483 to 590 species, among them scleractinian composed 219 species. On the sufficiently homogeneous distribution of corals and accompanying macrobenthos was typical for the reefs of the central Vietnam [27].

Zonal distribution of corals could be traced most clearly in open stony reef slopes, at shallow terraces and reef-flats of closed inlets in the presence of organogenic substrate of even small capacity. A similar situation [28] was observed by C. Dai [29] in Taiwan and by Yu. Latypov [30] in North and South Vietnam.

Investigation of reefs of $\mathrm{Ku}$ Lao Cham Islands (Central Vietnam), conducted by us in the last decade of May of 2010, made a distressing and painful impression. Practically nothing was left from the former richness and beauty of reefs of the reserved islands (Figure 3). Only 26 scleractinian species were revealed a result of three days of intensive survey conducted by hydrobiological experts, who spent underwater more than 48 hours and were equipped with modern photo techniques. The species composition was reduced10-because of mortality of coral reefs along the entire coastline of these islands (Figure 4). There has been a reduction in the coverage of the substrate of Scleractinian

Table 2. Cover of hard corals and soft corals before and after the typhoon attack, \% covering of substratum.

\begin{tabular}{ccccccc}
\hline Subject & $\begin{array}{c}\text { Algal-coral } \\
\text { community }\end{array}$ & $\begin{array}{c}\text { Inner } \\
\text { reef-flat }\end{array}$ & $\begin{array}{c}\text { Outer } \\
\text { reef-flat }\end{array}$ & $\begin{array}{c}\text { Soft coral } \\
\text { community }\end{array}$ & $\begin{array}{c}\text { Porites }+ \\
\text { Goniopora } \\
\text { community }\end{array}$ & Reef slope \\
\hline Macrophytes & $10-40 / 5-7$ & $7-10 / 10$ & $3-5 / 7-10$ & $3-5 / 10-12$ & $3-5 / 10-20$ & $1-5 / 5-7$ \\
Scleractinian & $10-15 / 0$ & $3-5 / 0.01$ & $45-60 / 0.1$ & $15-20 / 0.01$ & $100 / 0.0$ & $75-100 / 0.01$ \\
Alcyonarian & $3-7 / 10-18$ & $10 / 10$ & $15 / 45$ & $40-75 / 80-100$ & $0.0 / 100$ & $5-10 / 40-50$ \\
\hline
\end{tabular}




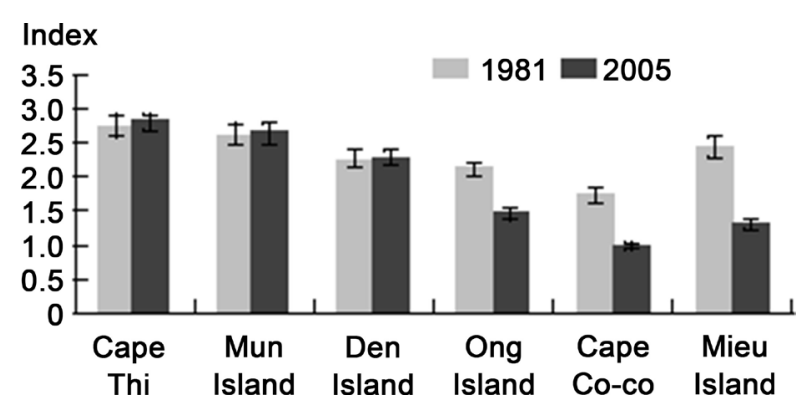

Figure 4. The cariation of the index of species diversity in reefs of the Nha Trang Bay.

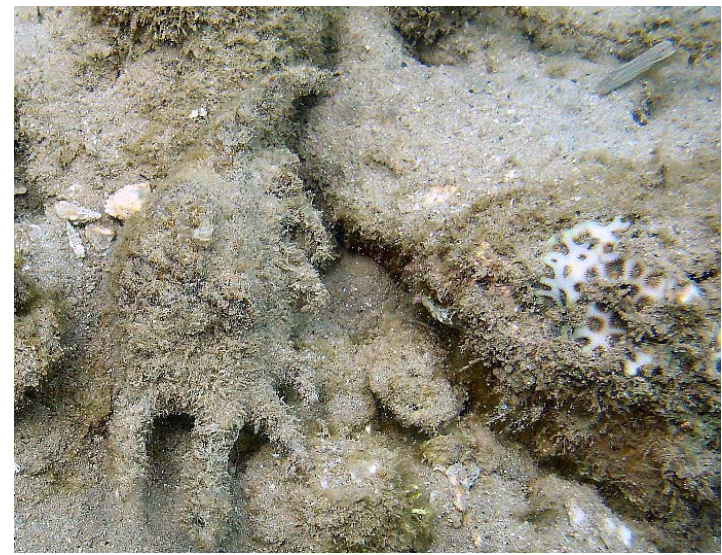

Figure 5. Substrate silting. Motile gastropod Lambis lambis at the left, a dead Faviidae colony at the recto.

and their replacement them by Alcyonarian. A heavy silting of substrate was the first thing noticed when diving. Even vagile animals were covered with a layer of sediments (Figure 5). At the same time, occurring almost everywhere alcyonarian and only single small scleractinian colonies, mostly also covered with silty sediments and various epibionts, were typical for the reefs. Representatives of the Acroporidae family, which are mandatory members of all living reefs and usually form the bulk of their species diversity and a high degree of substrate cover by living corals, were completely absent at the reefs. Reduction of species diversity of corals, degrees of substrate cover by corals, and growth delay with the increase of sedimentation has been mentioned in some publications [29] [30] [31]. Besides, intensive sedimentation can prevent coral larvae from settling and single scleractinian, found here and there $\left(2-4\right.$ colonies $\left./ \mathrm{m}^{2}\right)$, are presented mainly by suppressed colonies of massive shape with maximum size of $10 \mathrm{~cm}$ in diameter. Massive Porites colonies (40\%) and representatives of Favia and Goniastrea (12\% each) were the most frequent. Blue corals Heliopora coerulea are distributed practically at all transects with a frequency of $7 \%-10 \%$. In situations like that it is possible to talk about absence of any degree of substrate cover by live corals or about its minimal size which as on the whole makes a small portion of $1 \%$. Colonies of massive Porites up to 1.5 - $2 \mathrm{~m}$ in diameter, which can ensure up to $25 \%$ - $40 \%$ degree of substrate cover on some areas of the transect, were found only near Tai Island. Distribution of massive Porites is generally caused by the fact that these corals are able not only 
to survive in stressful environmental conditions but to reach dominance over the other scleractinian in productivity of organic material, degree of substrate cover and species richness.

Occurring everywhere, 10 - 15 species of soft corals play the main role in formation of communities on the present reefs of Ku Lao Cham Islands. Sarcophytum trochelioforum and Sinularia dura, which earlier prevailed among alcyonarian both in occurrence frequency and in the ability to make sure $100 \%$ cover of the substrate, dominate. Foraminifers, bryozoans, serpulids and drilling mollusks Litophaga spp. gain ground in the forming community together with scleractinian and macrophytes, which designates ecological type of succession of coelobytic and cryptic organisms [32].

During the visit to the islands in 2013, it was recorded that the reefs that had been damaged seven years before had begun to recover. In the northwestern end of the island, almost intact coral populations were found, which were represented mainly by massive and encrusting-massive colonies of Porites, Diploastrea, Platygyra, Favia, Goniastrea, and Goniopora. The Goniopora (20\% occurrence), Platygyra (8.5\%), Pocillopora (6\%), and Favites (5.7\%) species were widespread in the damaged reef. Moreover, the reproduction of the newly settled scleractinian Platygyra daedalea was recorded (Figure 6). This coral is a hermaphrodite; thus, it does not need a mate for breeding, as the same colony produces both eggs and sperm. It is also important that the larvae settle while undergoing metamorphosis within 3 - 4 days after fertilization, while in the absence of a substrate their planula retains the ability to settle for 3 months.

In October 2009, the Vietnam landfall of typhoon "Ketsana", which reached gusts of wind up to $165 \mathrm{~km} / \mathrm{h}$ corresponded to category 2 on a scale Saffir-Simpson Hurricane. Typhoon was accompanied by heavy rainfall (about $200 \mathrm{~mm}$ of rain), and the excitement of the sea more than two meters tall. After comparable in strength typhoon corals are destroyed at depths greater than $12 \mathrm{~m}-60 \%$ to $80 \%$ - between $12 \mathrm{~m}$ and $30 \mathrm{~m}$ and $100 \%$ - beyond $35 \mathrm{~m}$, where as earlier living coral cover age ranged from $60 \%$ to $75 \%$ in these zones. Most of the reefs of the island Tho Chu (Thailand Gulf) were almost destroyed, when the coastal zone at depth of $5.3 \mathrm{~m}, 40 \%$ of its corals were destroyed; at depth of $5-8 \mathrm{~m}$ in the settlement of Acropora-100\%; at depth of $8-12 \mathrm{~m}-60 \%$; 5.3 m, $40 \%$ of its corals were destroyed; at depth of $5-8 \mathrm{~m}$ in the settlement of Acropora$100 \%$; at depth of $8-12 \mathrm{~m}-60 \%$; at depth of $12 \mathrm{~m}-10 \%$. In this regard, it is proper to

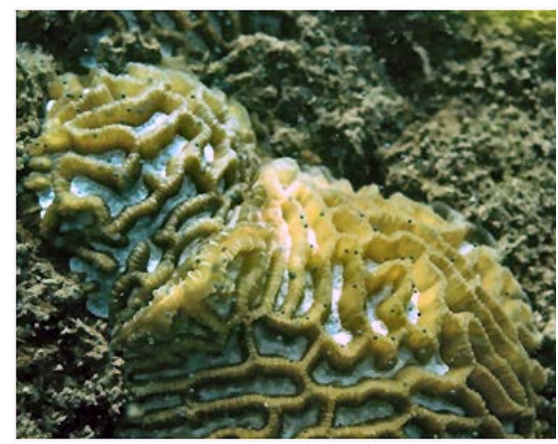

Figure 6. The reproduction of the newly settled scleractinian Platygyra daedalea. 
go back briefly to the information about the state of these reefs of quarter century ago. Typhoon caused significant damage of richness scleractinian species declined by almost a third (from 275 to 95 species). There are decreased by 2 - 3 times of substrate coral cover as well as an index of species diversity.

Organisms with calcareous skeletons, especially crustacean calcareous algae, play the main role at the initial succession stages in formation of a stable substrate for settling and growth of hermatypic corals. In 2 - 3 years after calcareous substrate formation the dominance of reef building coral colonies become many, and only in 4 - 6 years after the beginning of a new reef colonization appearance of vast colonies of Acropora corals is possible [33]. However, a hope for restoration of the studied reefs is available, as we nevertheless managed to find single, very small, young, settled a new colony of Pocillopora verrucosa-one from mass scleractinian species on all Indo-Pacific reefs.

Satisfactory data for recovery of reef ecosystems are obtained as a result of experiments and research on artificial breeding colonies of coral fragments. The results show the success of such works show their reliability and prospects. You can choose a variety of coral species, size and some fragments of space for their transplants, and many other factors and conditions [34]. Transplanted coral fragments regenerate faster than their natural donor colony; they recovered and increased in size by more than $200 \%$ of the original size and the number of branches. The orientation of their attachment to the frame has no effect on the experimental growth rate and colony morphology [1] [17] [22] [23] [31] [34].

The successful growth of transplanted fragments and the formation of large colonies contributed to the invasion of the damsel fish Dascyllus reticulates (Pomacentridae) into the new coral assemblages (Figure 7). This coral reef fish demonstrates a pronounced homing behavior in the formed coral reefs, similar to that in the natural reef, where adult fish usually live in groups in thickets of branched corals and seldom leave by more than a distance of one $\mathrm{m}$. Catch rates of fish around artificial reefs are often higher than catch rates in surrounding non-reef areas, leading to the perception of "enhanced" fisheries [1] [32] [33] [34].

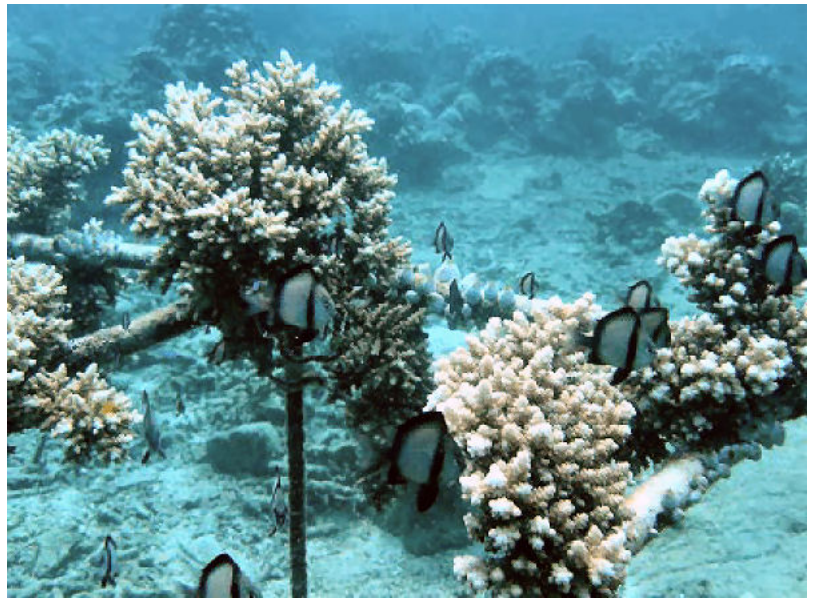

Figure 7. Restoring part of the ecosystem on the artificially cultivated reefs. 


\section{Conclusions}

Coral reef-sustainable ecosystem, regenerating mechanical injuries, practices almost any severity within 10 - 25 years. Periodically, the existing damage on the reef resulted in frequent repetition of pioneer stages of ecological succession and because of this is converted at least algal community the reef top. The more heavily damaged coral reef ecosystems prevent its regeneration from the cumulative effects of mechanical depletion and pollution of water environment.

In many works, which are not necessary to cited here, they analyze the level of physical and biological effects, resulting in disruption of species composition and structure of coral communities. At that, it universally recognized that the state of coral reefs was noticeably becoming worse on the global level. At present, it is essentially to know what we are trying to do to keep diversity of corals on a certain reef, its fish resources or ecosystem as a whole. Changes may take place on the level of an individual, population, ecosystem and landscape. Impacts affecting these levels can be short-term and longterm. Short-term impacts can shadow long-term ones. Only long-term monitoring, including single, short-term and long-term natural and anthropogenic impacts, will allow us to estimate stability of coral reef communities and to identify the tendency and reasons of changes. At the same time, it is necessary to see strictly technologies of marine objects cultivation in the areas of aquaculture, to expand areas and number of preserved and protected zones together with artificial restoration of biological diversity of reef-building scleractinian on reefs. All that will allow us not only to preserve and restore, but also to use rationally the unique ecosystem of global reefs.

\section{References}

[1] Latypov, Yu.Ya. (2014) Species Composition and Distribution of Scleractinian on Reefs of Wan Phong and Nha Trang Bays (South Vietnam). International Journal of Advanced Research in Biological Sciences, 1, 1-14.

[2] Loya, Y. and Slobodkin, L.B. (1971) The Coral Reefs of Eilat (Gulf of Eilat, Red Sea). Symposium Zoology Society London, 28, 117-139.

[3] Ravikovich, A.I. (1954) Modern and Fossil Reefs. M., 172.

[4] Preobrazensky, B.V. and Latypov, Yu.Ya. (1980) The Processes of the Regeneration of the Coral-Reef Ecosystem. Nauka, Moscow, 7-15.

[5] Latypov, Yu.Ya. (2007) Coral Reefs of Vietnam. Nauka, Moscow, 179. (In Russian)

[6] Baines, G.J.K. and Roger, F. (1976) Sequential Studies of Hurricane Deposit Evolution at Funafuti Atoll. Marine Geology, 21, 1-8.

[7] Harmelin-Vivien, M. (1994) The Effects of Storms and Cyclones on Coral Reefs: A Review. Journal of Coastal Research, 12, 211-231.

[8] Blanchon, P. (1977) Architectural Variation in Submerged Shelf-Edge Reefs: The Hurricane-Control Hypothesis. Proceeding of the 8 th International Coral Reef Symposium, Okinawa, 1977, 547-554.

[9] Gardner, T.A., Côté, I.M., Gill, J.A., Grant, A. and Watkinson, A.R. (2003) Long-Term Region-Wide Declines in Caribbean Corals. Science, 301, 958-960.

http://dx.doi.org/10.1126/science. 1086050 
[10] Latypov, Yu.Ya. and Selin, N.I. (2012) Changes of Reef Community near Ku Lao Cham Islands (South China Sea) after Sangshen Typhoon. American Journal of Climate Change, 1, 41-47. http://dx.doi.org/10.4236/ajcc.2012.11004

[11] Latypov, Yu.Ya. (2013) The Composition and Structure of Reef Community at Tho Chu Island (South China Sea) after Ketsana Typhoon. American Journal of Climate Change, 2, 284-291. http://dx.doi.org/10.4236/ajcc.2013.24028

[12] Dubatolov, V.N. (1961) O regeneration by Paleozoic Coral. Palaeontological Journal, 1, 7578.

[13] Connell, J.H. (1973) Population Ecology of Reef-Building Corals. In: Jones, O.A. and Endean, R., Eds., Biology and Geology of Coral Reefs, Academic Press, New York, 205-245. http://dx.doi.org/10.1016/B978-0-12-395526-5.50015-8

[14] Bak, R.P.M. and Steward-van, Es.Y. (1980) Regeneration of Superficial Damage in the Scleractinian Corals. Agaricia agaricites and Porites astreoides. Bulletin of Marine Sciences, 30, 883-887.

[15] Loya, Y. (1976) Skeletal Regeneration in a Red Sea Scleractinian Coral Population. Ibid, 261, 490-491. http://dx.doi.org/10.1038/261490a0

[16] Latypov, Yu.Ya. (2006) The Common Coral of Vietnam: Field Handbook. Far Eastern National University Press, Vladivostok, 148.

[17] Volkova, K.N., Latypov, Yu.Ya, and Khaisnikova, K.B. (1978) Ordovician and Silurian of the Verchoyan (Biostratigraphy and Palaeontology). Nauka, Moscow, 220.

[18] Stoddart, D.R. (1969) Posturricane Changes on the British Honduras Reef and Cays: Resurvey of 1965. Atoll Research Bulletin, 131, 1-25. http://dx.doi.org/10.5479/si.00775630.131.1

[19] Stephenson, W.R. (1958) An Ecological Survey at the Marine Fauna of Low Isles, Queensland. Australian Journal of Marine Freshwater Research, 9, 261-318. http://dx.doi.org/10.1071/MF9580261

[20] Rinkevich, B. and Loya, Y. (1989) Reproduction in Regenerating Colonies of the Coral Stylophora pistillata, Environmental Quality and Ecosystem Stability, Vol. IVB: Environmental Quality. Israel Society for Environmental Quality Sciences Publication, Jerusalem, 259-265.

[21] Ocubo, N., Taniguchi, H. and Motokawa, T. (2005) Successful Methods for Transplanting Fragments of Acropora formosa and Acropora hyacinthus. Coral Reefs, 24, 333-342. http://dx.doi.org/10.1007/s00338-005-0496-0

[22] Mohammed, T.A., Hamed, A., Habib, N., El-Arab Ma, E. and El-Moselhy, K. (2012) Coral Rehabilitation Using Steel Slag as a Substrate. International Journal of Environment Protection, 2, 1-5.

[23] Schumacher, H. (1976) The Initial Phase in Reef Development, Studied at Artificial Reef Models off Eilat, Red Sea. Intern Helgoland SympAbstrs, Hamburg, 59.

[24] Benayahu, Y. and Loya, Y. (1977) Quantitative Characteristics of Community Structure of Stony Corals, Soft Corals and Algae in the Nortern Gulf of Eilat (Red Sea). Intern Helgoland Symp Abstrs, Hamburg, 3-4.

[25] Dart, J.K.G. (1972) Echinoides, Algal Lawn and Coral Recolonization. Nature, 239, 50-51. http://dx.doi.org/10.1038/239050a0

[26] Latypov, Y.Y. (2011) Scleractinian Corals and Reefs of Vietnam as a Part of the Pacific Reef Ecosystem. Open Journal of Marine Science, 1, 50-68. http://dx.doi.org/10.4236/ojms.2011.12006

[27] Latypov, Y.Y. (1999) Benthic Communities of Coral Reefs of Tho Chu Island (Gulf of Siam, 
South China Sea). Biologia Morya, 25, 233-241.

[28] Sakai, K. and Nishihira, M. (1991) Immediate Effect of Terrestrial Runoff on a Coral Community near a River Mouth in Okinawa. Galaxea, 10, 125-134.

[29] Latypov, Y.Y. (2000) Macrobenthos Communities on Reefs of the An Thoi Archipelago of the South China Sea. Russian Journal of Marine Biology, 26, 18-26.

http://dx.doi.org/10.1007/BF02759489

[30] Choi, D.R. (1984) Ecological Succession of Reef Cavity-Dwellers (Coelobites) in Coral Rubble. Bulletin of Marine Science, 35, 72-79.

[31] Sutton, S.G. and Bushnell, S.L. (2007) Socio-Economic Aspects of Artificial Reefs: Considerations for the Great Barrier Reef Marine Park. Ocean and Coastal Management, 50, 829846. http://dx.doi.org/10.1016/j.ocecoaman.2007.01.003

[32] Mohammed, S.A.A. (2009) Coral Reef Restoration and Artificial Reef Management, Future and Economic. The Open Environment and Engineering Journal, 2, 37-49. http://dx.doi.org/10.2174/1874829500902010037

[33] Ohba, H.K., Hashimoto, K., Shimoike, T. and Fujioka. Y. (2008) Secondary Succession of Coral Reef Communities at Urasoko Bay, Ishigaki Island, the Ryukyus (Southern Japan). 11 th International Coral Reef Symposium, Ft Lauderdale, 7-11 July 2008, 319-327.

[34] Latypov, Yu.Ya., Ly, B.M.L., Hoang, H., Long, P.Q. and Kho, N.B. (2013) Experimental Artificial Cultivation of Corals from Colony Fragments. Russian Journal of Marine Biology, 39, 148-152. http://dx.doi.org/10.1134/S1063074013020053

\section{Submit or recommend next manuscript to OALib Journal and we will provide best service for you:}

- Publication frequency: Monthly

- 9 subject areas of science, technology and medicine

- Fair and rigorous peer-review system

- Fast publication process

- Article promotion in various social networking sites (LinkedIn, Facebook, Twitter, etc.)

- Maximum dissemination of your research work

Submit Your Paper Online: Click Here to Submit

Or Contact service@oalib.com 